\title{
Apoptosis during folliculogenesis in pigs
}

\author{
H. D. Guthrie and W. M. Garrett \\ Germplasm and Gamete Physiology Laboratory, Agricultural Research Service, \\ US Department of Agriculture, Beltsville, MD 20705, USA
}

The number of female germ cells in pig fetuses decreases by $70 \%$ between day 50 after mating and day 300 after birth. Approximately $55 \%$ of antral follicles undergo degeneration (atresia) except during the 3 days before oestrus, when only $15 \%$ of the follicles survive to ovulate. Apoptosis, a form of programmed cell death, is recognized as the mechanism of germ cell death and follicle atresia at all stages of folliculogenesis. The internucleosomal cleavage of genomic DNA caused by caspase-induced deoxyribonuclease activity was measured in pig granulosa cells by DNA fluorescence flow cytometry, densitometry of fluorescently labelled internucleosomal DNA fragments and immunohistochemical analysis of the $3^{\prime}$ end labelling of deoxyribonuclease-nicked DNA on frozen tissue sections. Follicular atresia during the 3 days before oestrus is associated with a $60-70 \%$ decrease in the secretion of FSH. In granulosa cells, apoptosis is associated with decreased cell proliferation and reduced production of oestradiol and inhibin. In cultured pig granulosa cells, FSH and IGF-I are anti-apoptotic and a caspase inhibitor blocked apoptosis, thereby providing evidence of caspase activity. Oocytes in most follicles have resumed meiotic maturation; therefore, one role for apoptosis and follicle atresia may be to act as a barrier to ovulation of oocytes that have not remained in meiotic arrest.

\section{Mechanism of apoptosis}

Apoptosis or programmed cell death is a physiological process that is essential for the successful development and survival of multicellular organisms (Vaux, 1993). The distinguishing characteristic of apoptosis is the ordered disassembly of cells from within a remodelling process required to remove cells that have completed their functions and are no longer needed, or that fail to develop properly, or that are damaged genetically. Apoptosis is triggered by environmental or physiological stimuli, or by withdrawal of trophic factors. As the predominant form of physiological cell death in eukaryotic cells, apoptosis requires energy utilization and is often regulated at the level of transcription or translation. These features of apoptosis distinguish it from necrosis, a pathological form of cell death, which is a result of injury and is characterized by swelling of the cell, activation of an immune response and lysis (Arends et al., 1990).

Physiological induction of apoptosis follows two general pathways: negative induction by survival factor withdrawal (Fig. 1a) and positive induction by specific ligand binding to a plasma membrane receptor (Fig. 1b). Six major components in these pathways have been 
(a)

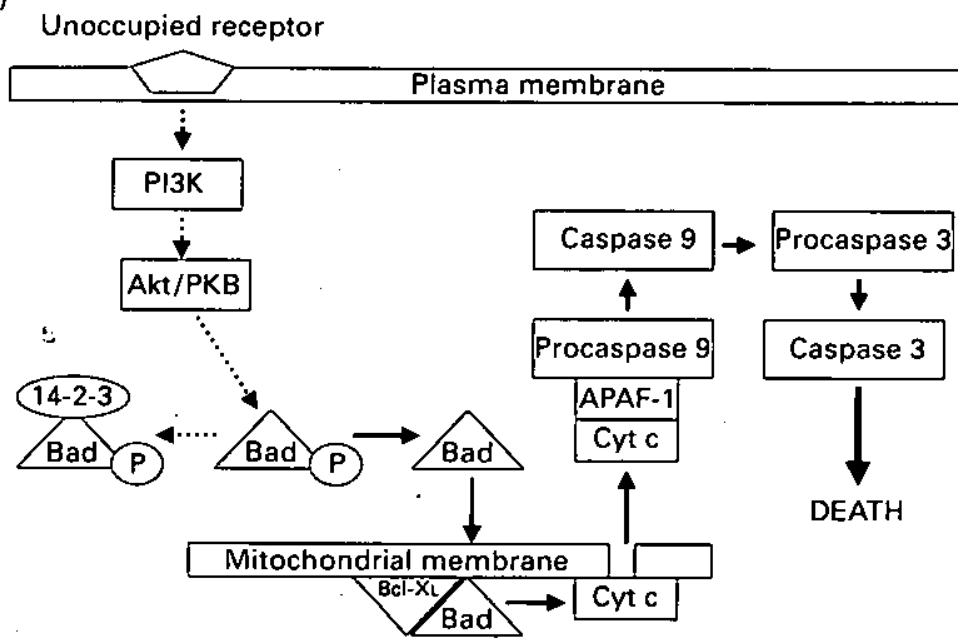

(b)

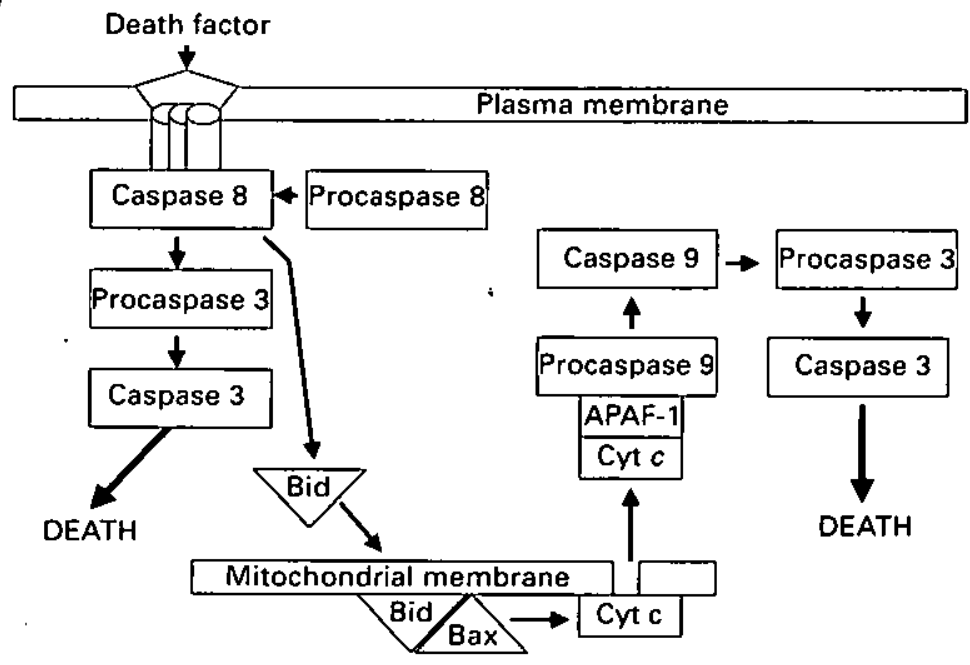

Fig. 1. Model for apoptosis pathway in pigs. (a) Negative induction by withdrawal of trophic or cell survival factors and (b) positive induction by specific ligand binding to plasma membrane receptors. In the negative induction pathway, receptor occupancy maintains a phosphorylation signal transduclion pathway to sequester phosphorylated pro-apoptotic B-cell lymphoma/ leukaemia-2 (Bcl-2) family proteins, such as $\mathrm{BCl}-\mathrm{X}_{\mathrm{L}} / \mathrm{BCl}-2$-associated death promoter (Bad) in the cytosol. If the receptor for a survival factor, such as FSH or insulin-like growth factor (IGF-I), is vacated then the phosphorylation signal transduction pathway is disabled; Bad is dephosphorylated and translocated to the mitochondrion. As a consequence of binding with an anti-apoptotic protein, such as $\mathrm{BCl}-2$ and $\mathrm{BCl}-2$-related gene-x long form $\left(\mathrm{BCl}-\mathrm{X}_{\mathrm{L}}\right)$, the outer mitochondrial membrane is destabilized and cytochrome $c(C y t$ ) escapes to initiate caspase activation, In the positive induction pathway, ligands, such as tumour necrosis factor, Fas and angiotensin II, occupy their membrane receptors to cause aggregation (trimerization) of plasma membrane receptors and orient receptor cytosolic-death domains into a configuration that recruits adlaptor proteins to promote the binding and activation of procaspases. Pro-apoptotic Bcl-2 proteins localized in the 
described to execute pro-apoptotic or anti-apoptotic processes in mammalian species. These components are: (i) plasma membrane receptors for cell survival factors and cell death factors; (ii) the B-cell lymphoma/leukaemia 2 (Bcl-2) family of proteins; (iii) cytochrome $\mathrm{C}$; (iv) apoptotic protease-activating factor 1 (APAF-1); (v) cysteinyl aspartate-specific proteases (caspases, interleukin-1 $\beta$-converting enzyme family); and (vi) inhibitory apoptosis proteins (IAP) (for reviews, see Ashkenazi and Dixit, 1998; Thornberry and Lazebnik, 1998; Desagher and Martinou, 2000; Guthrie and Garrett, 2000a).

Results from other studies indicate that the mitochondrion is a major target for the $\mathrm{BCl}-2$ proteins (Desagher and Martinou, 2000). Currently, $24 \mathrm{Bcl}-2$ proteins have been identified in mammals. Each member of the family contains at least one of four regions of $\mathrm{Bcl}-2$ homology that permit $\mathrm{BCl}-2$ proteins to form homo- and heterodimers to regulate each other. The $\mathrm{Bcl}-2$ proteins possess either anti-apoptotic or pro-apoptotic function. For the most part, the antiapoptotic members bind to the outer mitochondrial membranes and the pro-apoptotic members are distributed in both the cytosol and mitochondria. The primary mechanism by which $\mathrm{BCl}-2$ proteins regulate apoptosis is by controlling the release of cytochrome $c$ from the mitochondrion into the cytosol, where it coordinates the activation of caspases. The release of cytochrome $c$ from the mitochondrion initiates the 'caspase cascade' and serves as the critical point of control for apoptosis. In the cytosol, cytochrome $c$ forms a complex with APAF-1, dATP and procaspase 9 resulting in proteolytic activation of 'initiator' caspases, such as caspase 9. Caspase 9 subsequently activates downstream 'effector' caspases, such as caspase 3 , which functions to degrade cellular components or activate other substrates (Fig. 2) by proteolytic attack (Enari et al., 1998).

Caspases are responsible for the inactivation or activation of protein activities that lead to the death or disassembly of affected cells, and are present as inactive pro-enzymes, most of which are activated by proteolytic cleavage themselves (Cohen, 1997; Miller, 1997). The execution phase of caspase activity is represented by caspase 3 which, serving as a substrate for initiator caspases, amplifies the earlier cell death signals, resulting in cleavage of vital cellular proteins for completion of the cell death pathway (Fig. 2).

The specific substrate targets of the execution phase of apoptosis that affect the final disassembly of the cell are varied. The actions and substrates include disruption of microfilaments (GAS2), cytoskeletal components (actin and fodrin), chromosome structure (lamin), the cell cycle (retinoblastoma protein), DNA repair (poly[ADPI-ribose polymerase), low density lipoprotein receptor expression (sterol regulatory element-binding proteins 1 and 2) and signal transduction (catalytic subunit of DNA protein kinase). The chromatin in the nucleus is supported by a scaffold of protein designated as the nuclear matrix. The final stages of apoptosis are characterized by the activation in the nucleus of a deoxyribonuclease, which cleaves DNA between nucleosomes into internucleosomal fragments.

The IAP family are cytoplasmic proteins that bind to, and inhibit the activity of, specific caspases that function in the cell death pathway (Roy et al., 1997).

cytosol, such as Bcl-2-related death gene (Bid), are activated by caspase action mediated through the Fas/ tumour necrosis factor apoptosis signal and are translocated to the mitochondrion for heterodimerization with other proapoptotic proteins such as $\mathrm{Bcl}-2$ associated-x-gene (Bax) to destabilize the outer mitochondrial membrane resulting in the release of cytochrome $c$. The positive induction pathway can initiate a 'caspase cascade' that results in a death process that can be independent of or dependent on changes in mitochondrial stability. Akt: serine-threonine kinase; APAF-1: apoptotic protease-activating factor 1; PI3K: phosphatidylinositide3-OH kinase; PKB: protein kinase $\mathrm{B}$. 


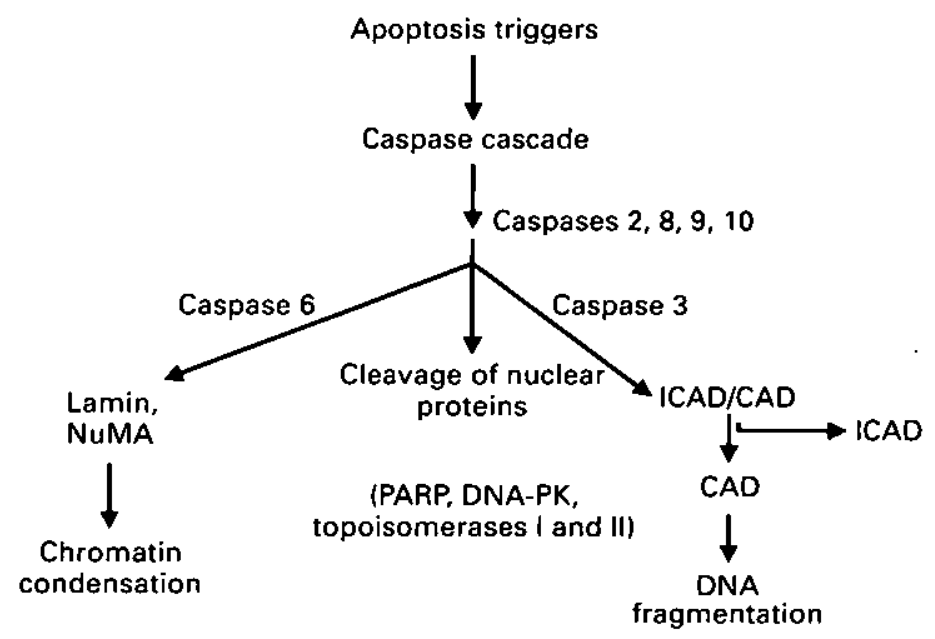

Fig. 2. Model for the role of caspases in nuclear apoptotic events showing the specific substrate targets of the execution phase of apoptosis leading to cleavage of genomic DNA into internucleosomal fragments. CAD: caspase-activated DNase; DNA-PK: DNA-dependent protein kinase; ICAD: inhibitor of CAD; NuMA: nuclear-mitotic apparatus protein; PARP: poly(ADP-ribose) polymerase.

\section{Folliculogenesis and apoptosis}

In pigs, the number of germ cells per female reaches a maximum of $1.2 \times 10^{6}$ in the fetus at day 50 after mating and then decreases sharply to $5.0 \times 10^{5}$ at parturition (Fig. 3). Germ cell development is dynamic in the fetus with proliferation, meiotic arrest, primordial follicle formation, primordial follicle activation and germ cell death occurring simultaneously in the same ovaries. In the ovaries of pig fetuses, about $5 \%$ of oocytes are undergoing apoptosis as indicated by the presence of pyknotic nuclei (Black and Erickson, 1968). Although germ cell death has not been studied extensively in pigs, in laboratory species it has been established that during early stages of oogenesis and folliculogenesis, apoptosis plays the primary role in oocyte degenerạtion (Pesce et al., 1993; Pesce and De Felici, 1994). Bcl-2 knockout mice have reduced numbers of primordial follicles (Ratts et al., 1995), and targeted overexpression of $\mathrm{BCl}-2$ in mouse ovarian somatic cells leads to reduced follicular atresia and increased litter size (Hsu et al., 1996). After parturition, the number of germ cells per female decreased at a slower rate to $2.0 \times 10^{5}$ at day 300 of age (Fig. 3). In pigs, preantral follicle growth begins within 10 days of birth (Erickson, 1967). Antral follicles are first observed histologically at about day 65 of age and emerge from the ovarian surface at about day 80 of age (Erickson, $1967 ; \mathrm{H}$. D. Guthrie, unpublished). We found that $\mathrm{BCl}-2$ was not expressed in germ cells and that expression was greatest in stromal cells located in the ovarian cortex surrounding primordial follicles and in the granulosa cells of primordial and preantral follicles (Garrett and Guthrie, 1999). This finding indicates that $\mathrm{Bcl}-2$ mediates its survival effect indirectly through stromal cell survival factors.

Granulosa cell apoptosis is the underlying molecular mechanism of follicular atresia (Hughes and Gorospe, 1991; Tilly et al., 1991; Guthrie et al., 1995). The incidence of follicular atresia, determined by pyknotic nuclei in granulosa cells, is lowest among primordial follicles $(\leqslant 6 \%)$ and preantral follicles $(\leqslant 17 \%)$, and greatest among antral 


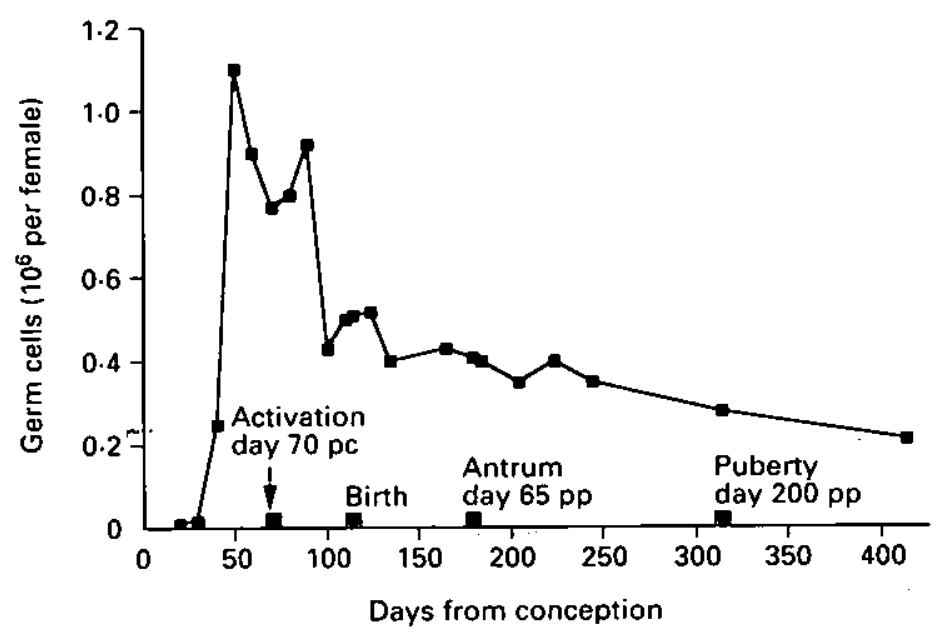

Fig. 3. Changes in the number of germ cells during folliculogenesis in female pigs showing key stages in development. Primordial follicle activation was first detected at day 70 post coitum (pc) and follicle antrum formation was first detected at day 65 post partum (pp) . (modified from Erickson, 1967; Black and Erickson, 1968).

follicles, averaging $55 \%$ in pre- and postpubertal gilts (Erickson, 1967; Dalin, 1987). The formation of antral follicles and the increased incidence of atresia during prepubertal development is coincident with a $60 \%$ decrease in mean plasma concentrations of FSH and LH between day 60 and day 120 of age (Guthrie and Garrett, 2000a).

\section{Ovarian regulation of atresia and apoptosis}

Biochemical characteristics of atresia and apoptosis have been investigated to discover causative factors and markers in an attempt to identify follicles in early stages of atresia. Results from studies of ovarian gene expression in vivo and in vitro have indicated that ovarian products, such as steroid hormones, transforming growth factor family members, insulin-like growth factor I (IGF-I), IGF-binding proteins and inhibins could play a role in the atretic process and apoptosis.

\section{Steroid hormones}

Follicles that contain $\geqslant 10 \%$ of apoptotic granulosa cells were found to have very low follicular fluid concentrations of oestradiol (1-5 $\mathrm{ng} \mathrm{ml}^{-1}$; Guthrie et al., 1995). Among nonatretic follicles, oestradiol concentrations were inversely related to the percentage of apoptotic $\left(\% \mathrm{~A}_{0}\right)$ granulosa cells $(r=-0.45 ; P=0.01 ; \mathrm{Fig} .4)$ at the beginning of a follicular phase, on day 1 after withdrawal of altrenogest and on day 6 of the oestrous cycle (Guthrie et al., 1995). It was concluded that low follicular fluid concentrations of oestradiol are a very early predictor of atresia. Loss of aromatase activity and enzyme protein (Guthrie and Garrett, 2000a) in granulosa cells is an important characteristic of atresia in follicles and may be mediated, in part, at transcription (Tilly et al., 1992a). 

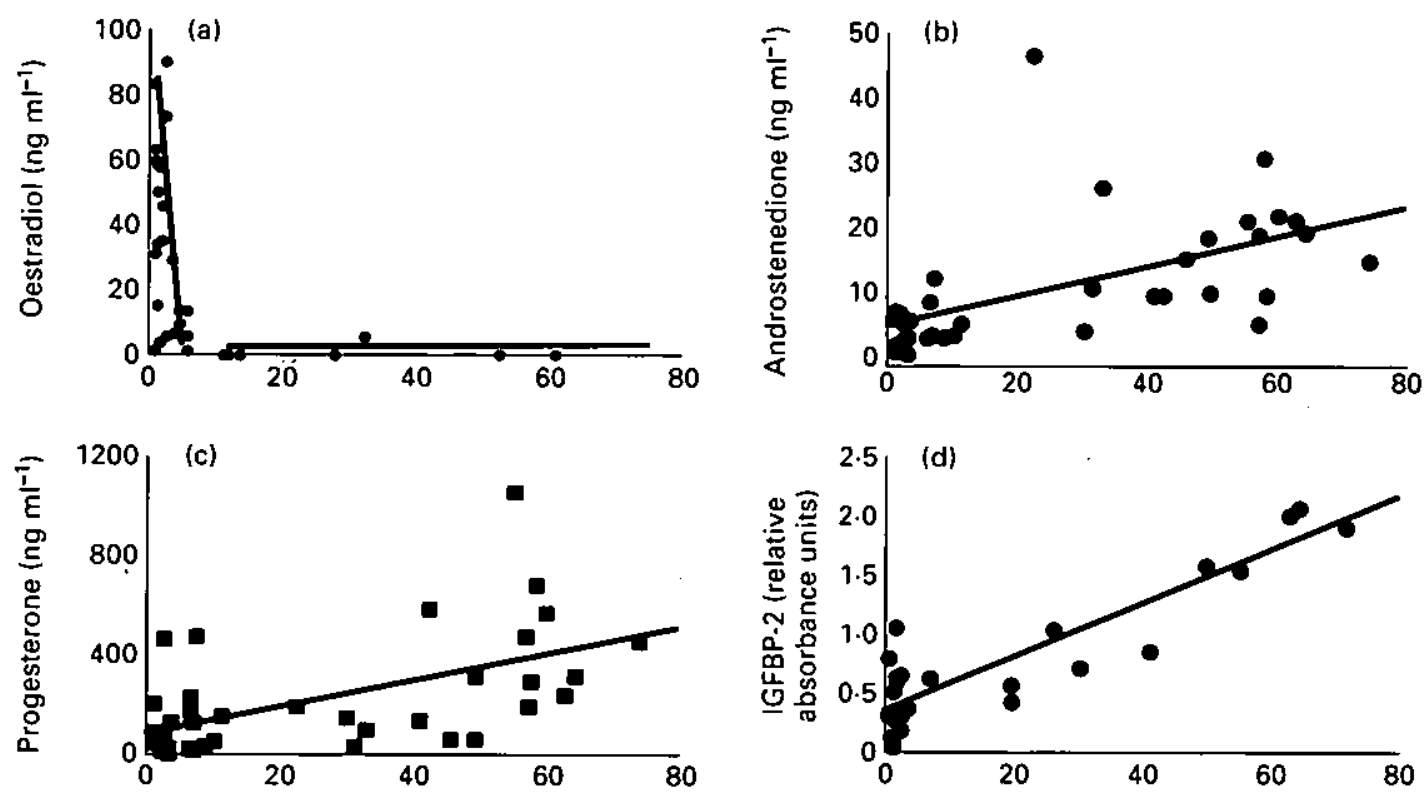

Percentage of apoptotic granulosa cells

Fig. 4. Linear regression of follicular fluid concentrations of (a) oestradiol, (b) androstenedione, (c) progesterone and (d) IGF binding protein 2 (IGFBP-2) on granulosa cell apoptosis in individual medium-sized nonatretic (< $10 \%$ apoptotic granulosa cells) and atretic $(\geqslant 10 \%$ apoptotic granulosa cells) follicles in pigs (modified from Guthrie et al., 1995).

Progesterone and androstenedione content of atretic follicles is similar to, or greater than, that of nonatretic follicles on days 6-7 of the oestrous cycle (Guthrie et al., 1995). Androstenedione and progesterone is were produced continuously in vivo in the follicular fluid as follicles became increasingly atretic as indicated by a greater proportion of apoptotic granulosa cells (Fig. 4). These results are in agreement with findings indicating that atretic pig follicles in culture release similar or greater amounts of androgen or progesterone to healthy follicles (Guthrie et al., 1995). The ability of atretic follicles to continue production of androgens and progesterone is probably due to the ability of theca cells to retain specific binding and steroid responsiveness to $\mathrm{LH}$ even in advanced stages of atresia, whereas specific binding of FSH in granulosa cells disappears relatively early during atresia (Tsafriri and Braw, 1984). The loss of specific binding of FSH in granulosa cells of atretic follicles may account, in part, for the loss of aromatase activity. Similarly, granulosa cells from atretic pig follicles were no longer able to release cAMP in response to exogenous gonadotrophins (Guthrie and Garrett, 2000a). In small pig follicles, expression of LH receptor and FSH receptor transcripts was localized to the theca interna and granulosa cells, respectively (Guthrie and Garrett, 2000a). In atretic follicles, LH receptor was expressed weakly in theca cells, whereas there was no expression of FSH receptor in granulosa cells (Guthrie and Garrett, 2000a).

Steroids modulate apoptosis in cultured granulosa cells of rats (Hsueh et al., 1994). Progesterone acting through a novel membrane receptor was shown to inhibit apoptosis in cultured granulosa cells of rats (Peluso and Pappalardo, 1994). In addition, the anti-apoptotic effect of epidermal growth factor (EGF) might also act by stimulating progesterone production. Progesterone production by pig granulosa cells in vitro was inversely related to apoptosis in the presence of FSH or IGF-I (Guthrie et al., 1998). This is in contrast to the positive correlation 
between follicular fluid concentrations of progesterone and the percentage of apoptotic granulosa cells during early stages of atresia in vivo (Guthrie et al., 1995).

In an attempt to clarify the role of progesterone in relation to apoptosis, the relationship between apoptosis and progesterone production in pig granulosa cells was examined using inhibitors of progesterone production and apoptosis. Although trilostane inhibited FSHinduced progesterone production, it did not affect the anti-apoptotic effect of FSH. When apoptosis was inhibited using the general caspase inhibitor benzyloxycarbonyl-valinylalaninyl-aspartyl fluoromethylketone (Guthrie et al., 2000), no effect on progesterone production was found. These results indicate that apoptosis and progesterone production are regulated independently by $\mathrm{FSH}$ in pig granulosa cells. In addition, although EGF also increased progesterone production in cultured pig granulosa cells, it did not have an antiapoptotic effect (H. D. Guthrie, unpublished).

Atresia is regulated by oestrogens and androgens in laboratory species (Tsafriri and Braw, 1984). Oestradiol benzoate was shown to block apoptosis in granulosa cells after the withdrawal of diethylstilbestrol (DES) in hypophysectomized, DES-treated, immature female rats (Billig et al., 1993). Furthermore, simultaneous treatment with testosterone prevented the anti-atretogenic effect of oestradiol benzoate, indicating that an interaction between locally produced oestrogen and androgen could regulate processes that trigger apoptosis and atresia. Further studies are required to determine the role of ovarian steroids on apoptosis and the atretic process in pigs.

\section{Role of inhibin and activin}

Apart from the initial primary role of inhibin as an endocrine regulator of pituitary function and of activin as a stimulator of pituitary cell FSH secretion (de Jong, 1988), evidence from granulosa cell culture indicates that inhibin and activin, dimers of inhibin-activin $\alpha$ and $\beta$ subunits, act as intra-ovarian paracrine factors, regulating multiple facets of follicular development (Hillier, 1991; Findlay, 1994). Other studies have shown that increased expression of inhibin-activin subunits is associated with follicle growth during the early luteal phase of the oestrous cycle in pigs (Guthrie et al., 1997; Garrett et al., 2000). Multiple molecular forms of inhibin or the $\alpha$ subunit are detectable in follicular fluid of atretic and nonatretic follicles during the follicular and the early luteal phase of the oestrous cycle (Guthrie et al., 1997). The high molecular mass forms of inhibin dimer $(227,121,69 \mathrm{kDa})$ were more abundant in nonatretic follicles than in atretic follicles, indicating a higher rate of inhibin synthesis. Expression of $\alpha$ and $\beta$ subunit mRNAs, and cytochrome P450 aromatase protein increased by 102 , 93 and $238 \%$, respectively, as nonatretic follicles grew from the $1-2 \mathrm{~mm}$ into the $3-5 \mathrm{~mm}$ size class (Garrett et al., 2000). In addition, expression of $\alpha$ and $\beta$ subunit mRNAs was positively correlated with the expression of a marker for cell proliferation, proliferation-associated nuclear antigen Ki-67 protein $(\alpha: r=0.571, P=0.0001$; and $\beta: r=0.594, P=0.0001)$. In contrast, as follicle atresia increased, as indicated by granulosa cell apoptosis, from the nonatretic to the late atretic stage, the expression of $\alpha$ and $\beta$ subunit mRNAs, cytochrome P450 aromatase protein and cell proliferation-associated nuclear antigen Ki-67 protein decreased by $70,83,66$ and $69 \%$, respectively (Garrett et al., 2000). These results indicate that granulosa cell proliferation and follicle growth are linked to the expression of inhibin-activin subunits. However, atresia was associated with a general decline in granulosa cell biosynthetic activity. In contrast, other findings indicate an atretogenic role for activin in vivo (Woodruff et al., 1990) and in vitro (Ford and Howard, 1997). However, these results might also be explained by stimulation of androgen production by theca interna or by a blockade of terminal granulosa cell differentiation. 

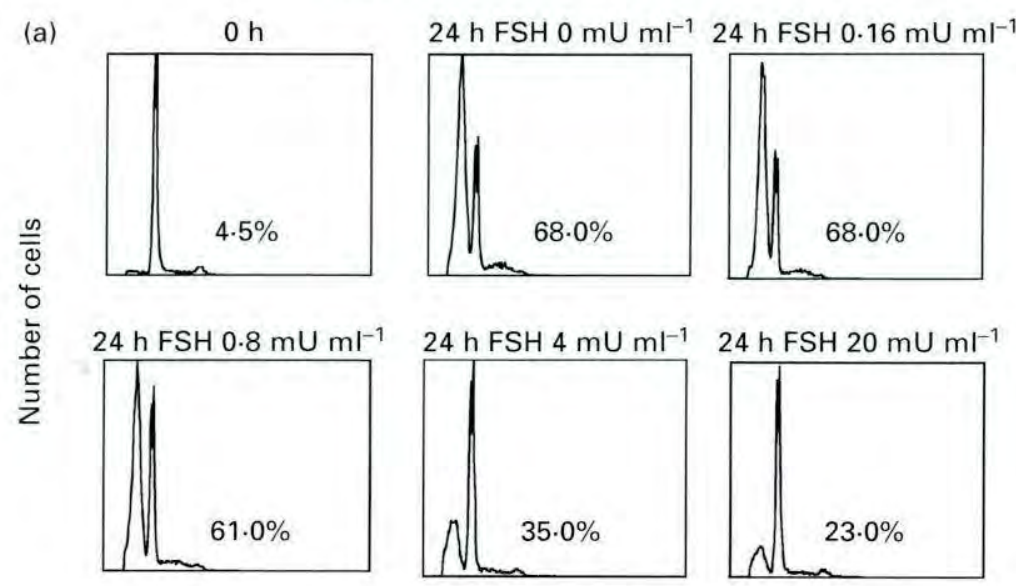

Amount of DNA

(b)

\begin{tabular}{crr} 
Lane & $\begin{array}{c}\text { Time } \\
(\mathrm{h})\end{array}$ & $\begin{array}{c}\mathrm{FSH}_{\mathrm{m}} \\
\mathrm{mU} \mathrm{m}^{-1}\end{array}$ \\
\hline 2 & 0 & 0 \\
3 & 24 & 0 \\
4 & 24 & $0 \cdot 16$ \\
5 & 24 & $0 \cdot 8$ \\
6 & 24 & 4 \\
7 & 24 & 20
\end{tabular}

1 Hind III $\lambda$ DNA

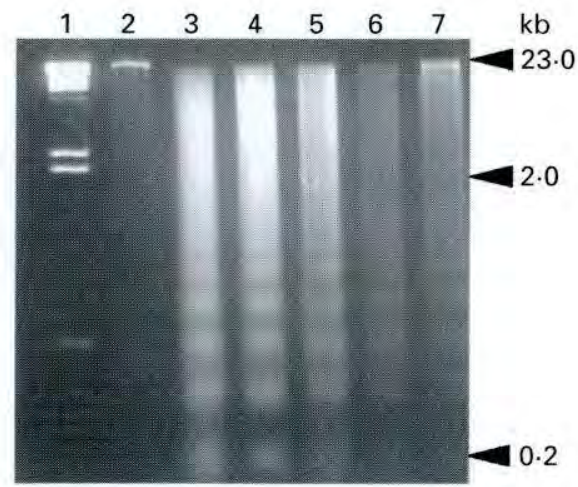

Fig. 5. Attenuating effect of FSH on apoptosis during $24 \mathrm{~h}$ culture of pig granulosa cells. (a) DNA histograms showing percentages of granulosa cells and (b) DNA internucleosomal cleavage showing low molecular weight DNA $(<23 \mathrm{kbp})$ fragments fractionated by agarose gel electrophoresis of DNA extracted from cells before culture (lane 2) and after culture (lanes 3-7). The absence of internucleosomal DNA fragments in lane 2 shows that the incidence of endogenous endonuclease activity was low before culture. DNA extracted from cells cultured for $24 \mathrm{~h}$ (lanes 3-7) shows an increase in DNA internucleosomal cleavage relative to noncultured cells and the attenuating effect of FSH (modified from Guthrie et al., 1998).

\section{FSH and growth factors in vitro}

Various growth factor pathways have been implicated in the growth, cell proliferation and differentiated cell functions of follicles (Hammond et al., 1993). Culture of granulosa cells or follicles from untreated or equine chorionic gonadotrophin (eCG)-treated rats have been useful models for the study of granulosa cell apoptosis because the granulosa cells in these experimental models undergo spontaneous or culture-induced apoptosis (Tilly et al., 1992b; Chun et al., 1994). Gonadotrophins, EGF, transforming growth factor $\alpha$, basic fibroblast 
growth factor and IGF-I have been described as follicle survival or anti-apoptotic factors capable of suppressing granulosa cell DNA fragmentation in rats (Hsueh et al., 1994).

Pig granulosa cells, like those of rats, undergo spontaneous or culture-induced apoptosis, and were used to test the hypothesis that FSH and IGF-I are anti-apoptotic, cell survival factors (Guthrie et al., 1998). Representative DNA histograms of granulosa cells isolated from one pig (Fig. 5a) show that the percentage of apoptotic granulosa cells increased from $4.5 \%$ in freshly isolated cells to $68.0 \%$ after $24 \mathrm{~h}$ in culture. Apoptosis in granulosa cells decreased by half $(P<0.01)$ in the presence of FSH $\left(4 \mathrm{NIH}-\mathrm{S} 1 \mathrm{mU} \mathrm{ml}^{-1}\right)$ and reached a plateau between 4 and $20 \mathrm{FSH} \mathrm{mU} \mathrm{ml} \mathrm{ml}^{-1}$. During the $24 \mathrm{~h}$ culture period, genomic DNA was cleaved into internucleosomal fragments forming 'DNA ladders' characteristic of deoxyribonuclease activity (Fig. 5b, lane 3). Internucleosomal cleavage was attenuated by $50 \%$ in the presence of $\mathrm{FSH}$ (Fig. 5b, lanes 6 and 7). IGF-I was also found to have an anti-apoptotic effect on granulosa cells (Guthrie et al., 1998). Apoptosis decreased by $50 \%$ in cells subjected to $50-250 \mathrm{ng}$ IGF-I $\mathrm{ml}^{-1}$ compared with cells cultured for $24 \mathrm{~h}$ in the absence of IGF-I.

There are biologically significant differences in the regulation of apoptosis in isolated pig and rat granulosa cells. In rats, IGF-I and FSH did not attenuate apoptosis in cultured granulosa cells (Tilly et al., 1992a; Hsueh et al., 1994). In contrast, Guthrie et al. (1998) found that both FSH and IGF-I attenuated apoptosis in pig granulosa cells, but that EGF was not effective (H. D. Guthrie, unpublished). In rats, apoptosis in granulosa cells was attenuated only when FSH and IGF-I were added to the culture of intact preovulatory follicles (Tilly et al., 1992a; Chun et al., 1994). A review of several studies in rats and pigs indicates that apoptosis decreased in culture conditions that promoted granulosa cell proliferation (Guthrie and Garrett, 2000a).

\section{The role of FSH in vivo}

Administration of charcoal-stripped pig follicular fluid induced changes in circulating concentrations of $\mathrm{FSH}$ in pigs indicating that $\mathrm{FSH}$ may play a critical role in maintaining a nonatretic population of follicles (Guthrie et al., 1987, 1988). A decrease in circulating concentrations of FSH of $60 \%$ after treatment with charcoal-stripped pig follicular fluid (compared with charcoal-stripped pig serum) was associated with a reduction $(P<0.05)$ in total ovarian mass (by $39 \%$ ) and of fluid volume (by $59 \%$ ), and with a reduction $(P<0.05$ ) in the number of $3-5 \mathrm{~mm}$ follicles from 29.6 to 2.9 per gilt (93\% decrease). Follicles remaining after treatment with charcoal-stripped pig follicular fluid were opaque, which is indicative of atresia (Guthrie et al., 1987). In another experiment, administration of FSH free of LH activity resulted in an increase $(P<0.05)$ in the number of $3-6 \mathrm{~mm}$ follicles compared with the saline control group (59.0 versus 30.8 per gilt, $48 \%$ increase) and restored the number of $3-6 \mathrm{~mm}$ follicles to that observed in the saline control group after charcoal-stripped pig follicular fluid treatment $(0.2$ versus 36.2 per gilt). There is a similar relationship between FSH secretion and the number of small and medium-sized follicles during the follicular phase and the periovulatory period of the next oestrous cycle. Selection and growth of the ovulatory cohort of follicles was accompanied by a $60-70 \%$ decrease in circulating concentrations of FSH and by atresia of non-ovulatory follicles and suspension of their replacement until after ovulation (Guthrie et al., 1995; Guthrie and Garrett, 2000a). Regrowth of 3-5 mm follicles after ovulation is temporally related to increased circulating concentrations of FSH (Guthrie and Garrett, 2000a). During the cell differentiation required for the maturation of ovulatory follicles, FSH appears to become less important as these events progress in the presence of low concentrations of plasma FSH and granulosa cell FSH receptor. The critical factor for the survival of ovulatory follicles may be the greater LH-responsiveness of ovulatory follicles, 
compared with non-ovulatory follicles, in terms of increased granulosa and theca cell L.H receptor expression (Guthrie and Garrett, 2000a), LH binding and increased granulosa LH-sensitive adenylate cyclase activity (Channing et al., 1982; Foxcroft and Hunter, 1985; Guthrie et al., 1995; Guthrie and Garrett, 2000a). On the basis of the effects of FSH treatment in vitro and regulation of $\mathrm{FSH}$ secretion in vivo, we conclude that $\mathrm{FSH}$ plays a role in growth and survival of small and medium-sized follicles by stimulation of granulosa cell proliferation and attenuation of granulosa cell apoptosis.

\section{Follicular IGF and IGFBP}

Although follicle atresia may be a result of decreased circulating concentrations of $\mathrm{FSH}$ and a reduction in the number of FSH receptors in the follicle population (Guthrie and Garrett, 2000a), an increase in the number of inhibitory IGF-I binding proteins (IGFBP) in granulosa cells may also play a role in biological neutralization of IGF-i (Hammond et al., 1993). Analysis of follicular fluid from follicles recovered during preovulatory maturation and during the early luteal phase showed that the amount of follicular fluid ICFBP-2 present was threefold greater in atretic than in nonatretic follicles (Guthrie et al., 1995). The quantity of IGFBP-2 was positively correlated with the percentage of apoptotic granulosa cells per follicle, during preovulatory maturation $(r=0.73 ; P \leqslant 0.001)$ and during the early luteal phase $(r=0.90$; $P \leqslant 0.001$; Fig. 4). Therefore, in several mammalian species, production or accumulation of IGFBP-2 may play a role in follicular atresia and granulosa cell apoptosis (Guthrie et al., 1995). In studies of gene expression in relation to atresia and apoptosis, it is clear that follicular cell proliferation and atresia are regulated by a complex interaction between the granulosa, theca interna and factors originating from the systemic circulation.

\section{Apoptotic pathway}

There is some evidence that caspase activity is associated with culture-induced apoptosis in pig granulosa cells (Guthrie et al., 2000). The percentage of apoptotic granulosa cells increased $(P<0.05)$ from $2.3 \%$ in freshly harvested granulosa cells to $33 \%$ after $24 \mathrm{~h}$ in culture. The caspase inhibitor benzyloxycarbonyl-valinyl-alaninyl-aspartyl fluoro methylketone reduced apoptosis to $3 \%$, which is similar to that in non-cultured cells. Reduction of granulosa cell apoptosis had no significant effect on steroidogenic activity during the culture period. Both APAF-1 and cytochrome $c$ are expressed in cultured mouse granulosa cells and caspase 3 was activated during culture-induced apoptosis (Robles et al., 1999). Further support for the role of caspases in ovarian apoptosis is that the expression of caspase 3 is associated with apoptosis in atretic follicles of rats (Flaws et al., 1995). A new anti-apoptotic pathway, the IAP protein family, has been found in the ovaries of mice and rats. These proteins may play an important regulatory role in granulosa cell apoptosis and follicle atresia because in rats two IAPs, X-link inhibitor of apoptosis (XIAP) and human inhibitor of apoptosis protein 2 (HIAP-2), are localized in the cytoplasm and nuclei of granulosa and theca cells of healthy follicles and had decreased to low and non-detectable values in granulosa and theca cells, respectively, in atretic follicles (Li et al., 1998). Another IAP, neuronal apoptosis inhibitory protein mRNA was strongly expressed in granulosa cells that were not undergoing apoptosis (Matsumoto et al., 1999). A physiological role of IAPs is strongly supported by the observation that expression of neuronal apoptosis inhibitory protein was increased 2.4-fold after the administration of equine chorionic gonadotrophin (eCG) and hCG, a treatment known to inhibit granulosa cell apoptosis both in vitro and in vivo. Evidence for the operation of the positive induction pathway is also present in ovarian tissue with expression of Fas and the Fas ligand in atretic follicles of the rat (Hakuno et al., 1996; Kim et al., 1998). 
Other signal transduction pathways may play a role in granulosa cell apoptosis and follicular atresia. An intense localization of angiotensin $\|$ receptor was found in atretic follicles of rats (Daud et al., 1988). Expression of the angiotensin II receptor in granulosa cells may be inhibited by FSH in healthy follicles (Pucell et al., 1988). If FSH support or FSH receptor function is lost, the angiotensin II receptor may be expressed and play a role in regulation of the atretic follicle. However, it remains to be established whether angiotensin II receptors are expressed as a result of atresia or whether expression of the receptors is involved in the mechanism of granulosa cell apoptosis. Although only limited studies have been conducted in pigs, clearly the physiologically regulated expression of the six major components of the apoptotic pathway are operating in the ovarian follicle and support the hypothesis that granulosa cell apoptosis is regulated through both negative and positive induction pathways.

\section{Conclusion}

The rationale for the production of so many germ cells during early fetal life and their subsequent loss in pigs and other species is unknown. One explanation of the importance of apoptosis and follicular atresia is that oocytes may have a limited finite lifespan when they reach full size. Up to $70 \%$ of oocytes in 3-5 mm diameter follicles have initiated germinal vesicle breakdown (GVBD) in prepubertal (Day and Funahashi, 1996; Grupen et al., 1997; H. D. Guthrie, unpublished) and post-pubertal gilts (Brüssow et al., 1996; Guthrie and Garrett, $2000 \mathrm{~b})$. The incidence of GVBD did not differ significantly between atretic and nonatretic follicles before the start of ovulatory follicle maturation; however, follicles containing oocytes undergoing GVBD are eliminated before the preovulatory $\mathrm{LH}$ surge (Guthrie and Garrett, $2000 \mathrm{~b}$ ). Therefore, apoptosis and follicle atresia may be physiologically important as a barrier to ovulation of oocytes that have not remained in meiotic arrest during the period of rapid maturation of the ovulatory cohort.

Mention of a trade name or proprietary product does not constitute a guarantee or warranty by the USDA and does not imply approval to the exclusion of others mentioned.

\section{References}

Arends ML, Morris RG and Wyllie AH (1990) Apoptosis. The role of the endonuclease American journal of Pathology 136 593-608

Ashkenazi A and Dixit VM (1998) Death receptors: signaling and modulation Science 281 1305-1308

Billig H, Furuta I and Hsueh AJW (1993) Estrogens inhibit and androgens enhance ovarian granulosa cell apoptosis Endocrinology 133 2204-2212

Black JL and Erickson BH (1968) Oogenesis and ovarian development in the prenatal pig Anatomical Record 161 45-56

Brüssow K-P, Torner H, Rátky J, Kanitz W and Köchling W (1996) Aspects of follicular development and intrafollicular oocyte maturation in gilts Reproduction in Domestic Animals 31 555-563

Channing CP, Anderson LD, Hoover DJ, Kolena J, Osteen KG, Pomerantz SH and Tanabe K (1982) The role of nonsteroidal regulators in control of oocyte and follicular maturation Recent Progress in Hormone Research $38331-408$

Chun S-Y, Billig H, Tilly JL, Fututa I, Tsafriri A and Hsueh AJW
(1994) Gonadotropin suppression of apoptosis in cultured preovulatory follicles: mediatory role of endogenous insulin-like growth factor I Endocrinology 135 1845-1853

Cohen GM (1997) Caspases: the executioners of apoptosis Biochemical Journal 326 1-16

Dalin A-M (1987) Ovarian follicular activity during the luteal phase in gilts Journal of Veterinary Medicine Series A 34 592-601

Daud Al, Bumpus FM and Husain A (1988) Evidence for selective expression of angiotensin 11 receptors on atretic follicles in the rat ovary: an autoradiographic study Endocrinology 122 2727-2733

Day BN and Funahashi $H$ (1996) In vitro maturation and fertilization of pig oocytes. In Biotechnology's Role in the Genetic Improvement of farm Animals pp 125-144 Eds RH Miller, VG Pursel and HD Norman. Beltsville Symposia in Agricultural Research $\mathrm{XX}$, American Society of Animal Science, Savoy, IL

de Jong FH (1988) Inhibin: fact or artifact Molecular and Cellular Endocrinology 13 1-10

Desagher S and Martinou IC (2000) Mitochondria as the 
central control point of apoptosis Trends in Cell Biology 10 369-377

Enari M, Sakahira H, Yokoyama H, Okawa K, Iwamatsu A and Nagata $S$ (1998) $A$ caspase-activated DNase thal degrades DNA during apoptosis, and its inhibitor ICAD Nature 391 43-50

Erickson BH (1967) Radioresponse of the pre-puberal porcine ovary International Journal of Radiation Biology 13 57-67

Findlay JK (1994) Peripheral and local regulators of folliculogenesis Reproduction, Fertility and Development 6 127-139

Flaws JA, Tilly JL, Hirshfield AN, Tilly KI, DeSanti A, Trbovich AM and Kugu K (1995) Interleukin-1 beta-converting enzyme-related proteases (IRPS) and mammalian cell death: dissociation of IRP-induced oligonucleosomal endonuclease activity from morphological apoptosis in granulosa cells of the ovarian follicle Endocrinology $1365042-5053$

Ford JJ and Howard HJ (1997) Activin inhibition of estradiol and progesterone production in porcine granulosa cells Journal of Animal Science 75 761-766

Foxcroft GR and Hunter MC (1985) Basic physiology of follicular maturation in the pig Journal of Reproduction and Fertility Supplement 33 1-19

Garrett WM and Guthrie HD (1999) Expression of Bcl-2 and 3-hydroxysteroid dehydrogenase protein during oocyte and follicle development in foetal and post-natal pig ovaries Reproduction, Fertility and Development 11 $463-470$

Garrett WM, Mack SO, Rohan RM and Guthrie HD (2000) In situ analysis of the changes in expression of porcine ovarian inhibin subunit messenger ribonucleic acids during the early luteal phase journal of Reproduction and Fertility 118 235-242

Grupen CG, Nagashima H and Nottle MB (1997) Asynchronous meiotic progression in porcine oocytes matured in vitro: a cause of polyspermic fertilization? Reproduction, Fertility and Development 9 187-191

Guthrie HD and Garrett WM (2000a) Factors regulating apoptosis during folliculogenesis in pigs Proceedings of the American Society of Animal Science http//wmw.asas. org/jas/symposia/proceedings/0933.pdí

Guthrie HD and Garrett WM (2000b) Changes in porcine oocyte germinal vesicle development as follicles approach preovulatory maturity Theriogenology $\mathbf{5 4}$ 389-399

Guthrie HD, Bolt D), Kiracofe GH and Miller KF (1987) Ovarian response to injections of charcoal-extracted porcine follicular fluid and porcine $\mathrm{FSH}$ in gilts fed a progesterone agonist, altrenogest fournal of Animal Science 64 816-826

Guthrie HD, Bolt DJ, Kiracofe GH and Miller KF (1988) Effect of charcoal-exiracted porcine follicular fluid and $17 \beta$-estradiol on follicular growth and plasma gonadotropins in gilts fed a progesterone agonist (altrenogest) Biology of Reproduction 38 750-755

Guthrie HD, Grimes RW, Cooper BS and Hammond IM (1995) Follicular atresia in pigs: measurement and physiology Journal of Animal Science 73 2834-2844

Guthrie HD, Ireland JLH, Good TEM and Ireland J] (1997) Expression of different molecular weight forms of inhibin in atretic and nonatretic follicles during the early luteal phase and altrenogest-synchronized follicular phase in pigs Biology of Reproduction 56 870-877

Guthrie HD, Garrett WM and Cooper BS (1998) Folliclestimulating hormone and insulin-like growth factor-l attenuate apoptosis in cultured porcine granulosa cells Biology of Reproduction 58 390-396

Guthrie HD, Garrell WM and Cooper BS (2000) Inhibition of apoptosis in cultured porcine granulosa cells by inhibitors of caspase and serine protease activity Theriogenology 54 731-740

Hammond JM, Samaras SE, Grimes R, Leighton J, Barber I, Canning SF and Guthrie HD (1993) The role of insulinlike growth factors and cpidermal growth factor-related peptides in intraovarian regulation in the pig ovary journal of Reproduction and Fertility 48 117-125

Hakuno N, Koji T, Yano T, Kobayashi N, Tsutsumi $O$, Taketani $Y$ and Nakane PJ (1996) Fas/APO-1/CD95 system as a mediator oí granulosa cell apoptosis in ovarian follicle atresia Endocrinology 137 1938-1948

Hillier SG (1991) Regulatory functions for inhibin and activin in human ovaries fournal of Endocrinology 131 171-175

Hsu SY, Lai RJ-M, Finegold $M$ and Hsueh AIW (1996) Targeted overexpression of $\mathrm{BCl}-2$ in ovaries of transgenic mice leads to decreased íllicle apoptosis, enhanced folliculogenesis and increased germ cell tumorigenesis Endocrinology $1374837-4843$

Hsueh Al, Billig H and Tsafiri A (1994) Ovarian follicle atresia: a hormonally controlled apoptotic process Endocrine Reviews 15 707-724

Hughes FM, Ir and Gorospe WC (1991) Biochemical identification of apoptosis (programmed cell death) in granulosa cells: evidence for a potential mechanism underlying follicular atresia Endocrinology 129 2415-2422

Kim IM, Boone DL, Auyeung A and Tsang BK (1998) Granulosa cell apoptosis induced at the penultimate stage of follicular development is associated with increased levels of Fas and Fas ligand in the rat ovary Biology of Reproduction $581170-1176$

Li J, Kim J-M, Liston R, Li M, Miyazaki T, Mackenzie AE, Korneluk RG and Tsang BK (1998) Expression of inhibitor of apoptosis proteins (IAPS) in rat granulosa cells during ovarian follicular development and atresia Endocrinology 139 1321-1328

Matsumoto K, Nakayama T, Sakai H, Tanemura K, Osuga H, Sato E and Ikeda J-E (1999) Neuronal apoptosis inhibitory protein (NAIP) may enhance the survival of granulosa cells thus indirecily affecting oocyte survival Molecular Reproduction and Development 54 103-111

Miller DK (1997) The role of the caspase family of cysteine proteases in apoptosis Seminars in Immunology 9 $35-49$

Peluso II and Pappalardo A (1994) Progesterone and cellcell adhesion interact to regulate rat granulosa cell apoptosis Biochemical Cell Biology 72 547-551

Pesce $M$ and De Felici $M$ (1994) Apoptosis in mouse primordial germ cells: a study by transmission and scanning electron microscope Anatomy and Embry. ology (Berlin) $189435-440$ 
Pesce M, Farrace MG, Piacentini M, Dolci S and De Felici $\mathbf{M}$ (1993) Stem cell factor and leukemia inhibitory factor promote germ cell survival by suppressing programmed cell dealh (apoptosis) Development 118 1089-1094

Pucell AG, Bumpus FM and Husain A (1988) Regulation of angiotensin 11 receptors in cultured rat ovarian granulosa cells by follicle-stimulating hormone and angiotensin II Journal of Biological Chenistry 263 11 954-11 961

Ratts VS, Flaws JA, Kolp R, Sorenson CM and Tilly JL (1995) Ablation of bcl-2 gene expression decreases the numbers of oocytes and primordial follicles established in the post-natal female mouse gonad Endocrinology $1363665-3668$

Robles R, Tao XI, Trbovich AM, Maravel DV, Nahum R, Perez, GI, Tilly K1 and Tilly IL (1999) Localization, regulation and possible consequences of apoptotic protease-activating factor-1 (Apaf-1) expression in granulosa cells of the mouse ovary Endocrinology 140 2641-2644

Roy N, Deveraux QL, Takahashi R, Salvesen CS and Reed JC (1997) The C-IAP-1 and C-IAP-2 proteins are direct inhibitors of specific caspases EMBO journal 16 6914-6925

Thornberry NA and Lazebnik $Y$ (1998) Caspases: enemies within Science 281 1312-1316
Tilly JL, Kowalski KI, Johnson AL and Hsueh AJW (1991) Involvement of apoptosis in ovarian follicular atresia and: postovulatory regression Endocrinology 129 2799-2801

Tilly IL, Kowalski KI, Schomberg DW and Hsueh AJW (1992a) Apoptosis in atretic ovarian follicles is associated with selective decreases in messenger ribonucleic acid transcripts for gonadotropin receptors and cytochrome $\mathrm{P} 450$ aromatase Endocrinology 131 1670-1676

Tilly JL, Billig H, Kowalski KI and Hsuch AJW (1992b) Epidermal growth factor and basic fibroblast growth factor suppress the spontaneous onset of apoptosis in cultured rat ovarian granulosa cells and follicles by a tyrosine kinase-dependent mechanism Molecular Endocrinology 6 1942-1950

Tsafriri A and Braw RH (1984) Experimental approaches to atresia in mammals. In Oxford Reviews of Reproductive Biology pp 226-265 Ed. IR Clarke. Clarendon Press, Oxford

Vaux DI. (1993) Toward an understanding of the molecular mechanisms of physiological cell death Proceedings National Academy of Sciences USA $90786-789$.

Woodruff TK, Lyon RJ, Hansen SE, Rice GC and Mayo KE (1990) Inhibin and activin locally regulate rat ovarian folliculogenesis Endocrinology 127 3196-3205 